\title{
Analysis of current and voltage harmonics introduced by the drive systems of a bucket wheel excavator
}

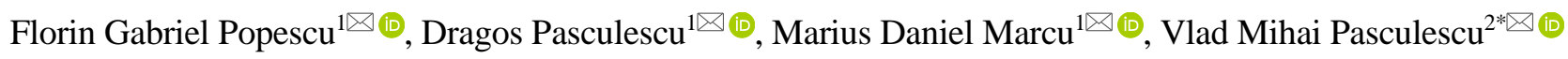 \\ ${ }^{1}$ University of Petrosani, Petrosani, 332006, Romania \\ ${ }^{2}$ National Institute for Research and Development in Mine Safety and Protection to Explosion - INSEMEX, Petrosani, 332047, Romania \\ *Corresponding author: e-mail vlad.pasculescu@insemex.ro, tel. +40765616288
}

\begin{abstract}
Purpose. The quality of electricity is a problem of major interest, making it necessary to analyze the factors and causes that result in the worsening of the electric energy quality. An important aspect of electricity quality is the introduction of current and voltage harmonics in the alternating current network by non-linear consumers. The paper analyzes the deforming regime introduced by the drive systems of a bucket wheel excavator within a technological line at an open pit mine.
\end{abstract}

Methods. The paper presents the measurements of power quality in a laboratory experimental study and measurements of an upgraded technological line at a lignite open pit. In this sense, the present the study of a distorting regime introduced by the drive systems formed from a static frequency converter and an asynchronous motor, as well as the results of quality power measurements introduced by the drive systems in the electric network.

Findings. The paper presents analysis of the voltage and current harmonics introduced in the alternating current network of static converter-asynchronous motor drive systems, which is necessary to establish the deformation factor. The values of the deforming regime are essential to obtain the harmonic compensation solutions.

Originality. The originality of the paper consists in the approach to the measurements performed and the analysis of the deforming regime introduced by the electric drive systems.

Practical implications. The values of the current and voltage harmonics were determined both by the laboratory measurements and by measurements made on the supply line of a bucket wheel excavator in different operating regimes.

Keywords: bucket wheel excavator, deforming regime, drive systems, electric current, lignite open pits, measurements, quality, voltage

\section{Introduction}

The quality of the electricity is a complex problem that resides in the multitude of factors that condition it, due to their interdependence, the lack of methods and means of obtaining expeditious and especially accurate information on certain sizes that characterize it [1].

In many cases, especially in the case of modern technologies, the end users are the ones that cause significant electromagnetic disturbances, which can affect the quality of the electricity provided to other users. In this case, the end-users must take the necessary measures to limit the disturbance to a level where the standard quality of electricity is not affected to other users [2].

A significant part of the equipment currently used requires a good quality of electricity. However, the same equipment often causes a distortion of the voltage supply to the installations due to their nonlinear characteristics, i.e. they lead to the appearance of a non-sinusoidal current when a sinusoidal voltage is applied. Thus, maintaining a satisfac- tory quality of electricity is a common responsibility of the electricity supplier and user [3].

The main causes of the deforming regime, induced by introducing voltage and current harmonics in the S.E.N., are the following:

- development of power electronics in the fields of electric machine drives, transmission of electricity over long distances, regulation of voltage and reactive power, industrial processes of electrostatic nature, and so on;

- increasing the number of non-linear consumers and the amount of power absorbed by them (electric welding devices, fluorescent lighting, and so on);

- raising the voltage levels in the operation of the very high voltage networks, due to their reactive power input (transformers, autotransformers, compensation coils and steel core devices, which increase their deforming contribution with the increase in the applied voltage due to saturation of the magnetic core) [4].

The propagation, amplification and compensation of the deforming phenomena, pose the following problems: 
a) avoiding or limiting the production of current and voltage harmonics;

b) avoiding or limiting the propagation of harmonics in electrical installations;

c) avoiding or limiting the effects of higher current and voltage harmonics;

d) compensation of the deforming regime, i.e. of the current and voltage harmonics at certain points of the network.

The widespread use of rectifiers for powering the inverters has the major negative consequence of increasing "harmonic pollution". The energy system can function properly in the presence of a limited "quantity" of harmonics. Until recently, injection of harmonics into the system could be considered insignificant. At present, however, the increasing dependence of consumers on equipment with non-linear characteristics means that this phenomenon can no longer be neglected. Introduction of harmonics in the electricity supply system is not the only problem, the operation of electrical equipment can also be affected [5].

The presence of harmonics in the power supply system can generate a wide range of unwanted effects. For example, harmonics can cause signal interference, overvoltage, data loss in data transmission lines. Harmonics can also cause overheating, malfunction of electrical equipment in general. Harmonics can get transformers and capacitors to overheat, reducing the life of these devices or damaging them. Another effect is heating of electric motors and the appearance of a pulsating torque. The presence of harmonics in the power supply system leads to general power losses, reduced efficiency of AC motors, increased maintenance cost [6].

The amplitude and order of the harmonic components depend on a series of factors: the source of harmonics, the power level of the system, the operation of the system in normal or resonance regime. Even the harmonics produced by a single installation can vary depending on its operating mode [7].

Nonlinear loads can also produce harmonics multiple of three. These require special attention, as they bring about current in the zero conductor, which can sometimes exceed the phase current in amplitude.

Considering the increase in the amount of electric power equipment, together with the full range of unwanted auxiliary effects presented above, different national and international organizations have issued recommendations regarding the limitation of the current harmonics injected into the network, to ensure maintaining the acceptable quality of the power network [8].

In lignite open pits, because of the specificity of the work carried out, the main objectives (fixed at the level of the European Community), to be satisfied by the applied technologies are: reduced consumption of raw materials, low energy consumption and the decrease in the deforming regime [9].

The main equipment used in technological flows from the lignite open pits is bucket wheel excavators (Fig. 1) [10]

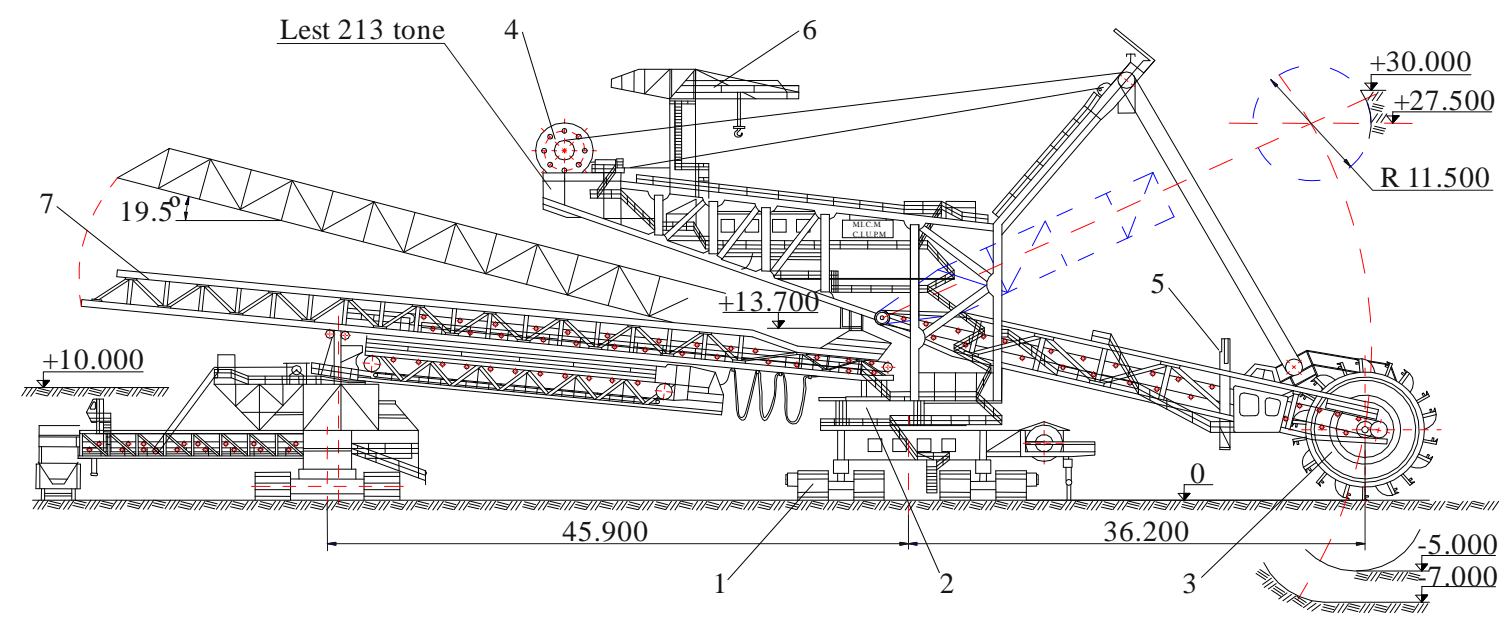

Figure 1. The functional structure of the ERc 1400-30/7 bucket wheel excavator (BWE): 1 -crawler travel mechanism; 2 -rotation mechanism; 3 -bucket wheel; 4 - boom lifting mechanism; 5 -command cabin operation mechanism; 6 -rotating 10 t crane; 7 - conveyor hoisting and moving mechanism

Technological process of exploiting the lignite deposits of lignite open pits comprises four phases: excavation, transportation and storage (sterile/charcoal), delivery (charcoal) [11], [12]. All stages are interrelated, and, from the functional point of view (power and capacity), the specialized technical equipment corresponds to the power and capacity of the primary equipment of the technological flow, which is bucket wheel excavators [13].

We can infer that the technological flow of lignite open pits is composed of excavating machines of continuous mode (bucket wheel excavators), transportation equipment (belt conveyor, belt track trolleys, crawler distribution trolleys, conveyor distribution), deposit equipment (dump cars, traversers bridges, bridges of direct dump) and storage equipment (field machine, salt harvester, combined machine to excavate and deposit) [14].
Considering the complexity of the excavator electric drive systems, the paper analyzes the deforming regime introduced by this type of equipment, both through laboratory measurements and through measurements made in a lignite open pit.

\section{The laboratory experimental study}

In this paragraph, we performed laboratory measurements for the study of deforming regime introduced by the drive systems with static frequency converter - asynchronous motor. The measurements were performed on a laboratory stand with the following equipment:

- asynchronous motor $P_{n}=3 \mathrm{~kW} ; \quad U_{n}=230 / 400 \mathrm{~V}$; $I_{n}=14 \mathrm{~A} ; \Omega_{n}=154.46 \mathrm{rad} / \mathrm{s}$; 
- indirect static VARISPEED F7 frequency converter, formed by uncontrolled rectifier and a vector-control inverter of power $4.5 \mathrm{~kW}$;

- DC generator functioning as brake for the load on the drive motor;

- equipment for energy quality analysis.

The schematic diagram for the measurement stand is shown in Figure 2.

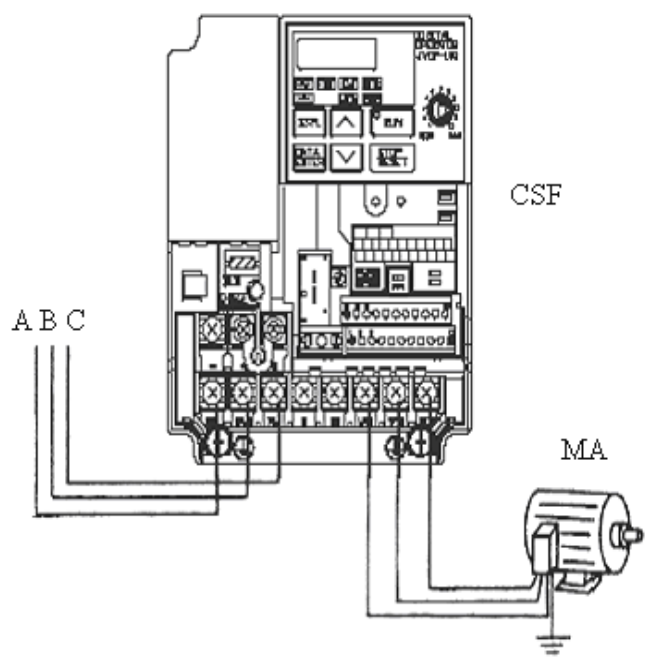

Figure 2. Assembly used in making the measurements

The measurements were made for operation with the following characteristics: start time at frequency $50 \mathrm{~Hz}$; $t=20 \mathrm{~s}$; timeout $t=10 \mathrm{~s}$. During measurements, the motor supply frequency was changed, the frequencies for which measurements were made were 45,50 and $55 \mathrm{~Hz}$.

The inverter used is controlled to operate at $U / f=$ constant carrier frequency of $2 \mathrm{kHz}$. The measurement results are shown in Figures 3 and 4. The measurements were carried out at start-up, frequency change, and different values of the voltage and the load, including no-load operation.

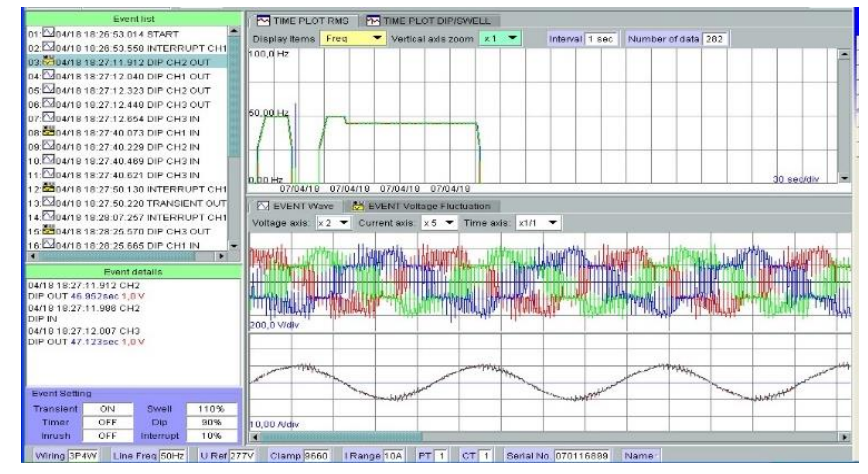

Figure 3. Variation the frequency of the output voltage during the experiment and the variation curves of voltage and electric current output

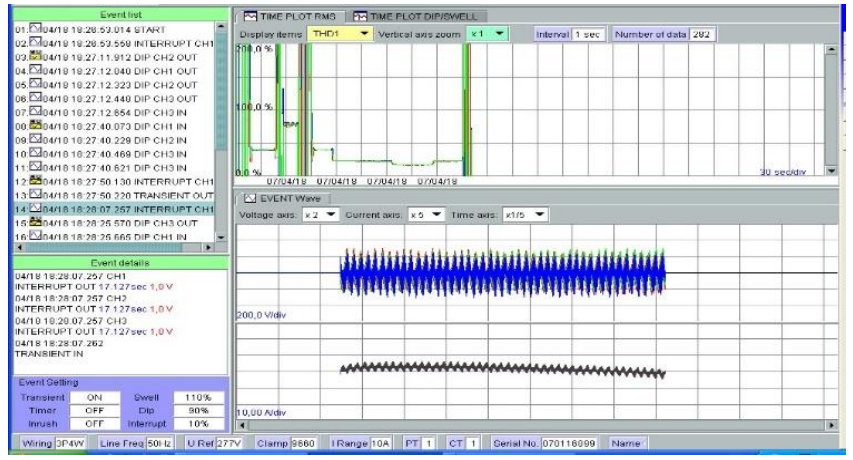

Figure 4. The THDI variation during the experiment and the variation curves of voltage and electric current

The harmonics spectrum is shown in Figure 5 for different cases. Analysis of data from Figure 5 highlights the fact that at the output of the inverter, the total harmonic distortion factor for voltage is greater than the total harmonic distortion factor for electric current. This is due to the specific mode of the voltage curves formation at the inverter output with PWM (Pulse Width Modulation) control. (a)

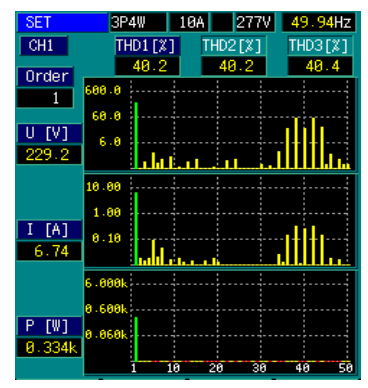

(b)

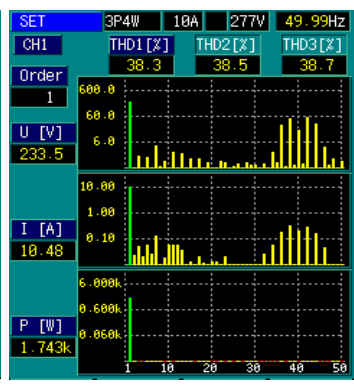

(c)

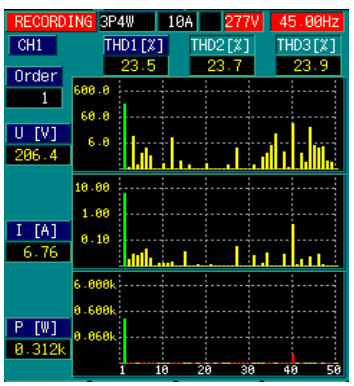

(d)

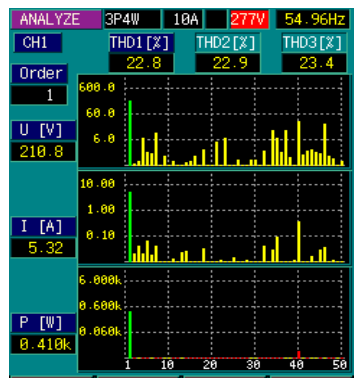

(e)

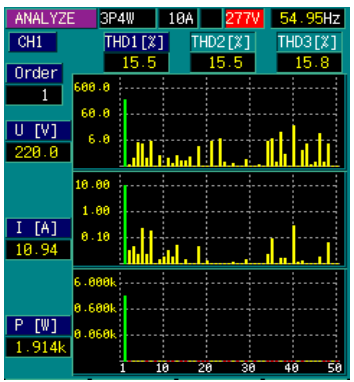

Figure 5. The harmonics spectrum recorded in the experimental study: (a) idle, $f=50 \mathrm{~Hz}$; (b) on load, $f=50 \mathrm{~Hz}$; (c) on load, $f=45 \mathrm{~Hz}$; (d) idle, $f=55 \mathrm{~Hz}$; (e) on load, $f=55 \mathrm{~Hz}$

The total harmonic distortion for voltage (THDU) is $40.3 \%$ at $50 \mathrm{~Hz}$ for idle regime, dropping slightly at full load $(37.9 \%)$. As the frequency decreases and the deforming regime changes, THDU $=22.9 \%$ for idle regime and THDU $=17.5 \%$ at full load at $45 \mathrm{~Hz}$ and $\mathrm{THDU}=22.4 \%$ for idle regime and $\mathrm{THDU}=15.8 \%$ at full load at $55 \mathrm{~Hz}$.

To analyze the influence of the carrier frequency of the harmonic spectrum of the inverter output quantities, the car- rier frequency value was set to $5 \mathrm{kHz}$. The experimental results of the tests are shown in Figures 6 and 7.

The spectrum of the harmonics for the carrier frequency $5 \mathrm{kHz}$ is shown in Figure 8. With increasing carrier signal frequency, the deforming regime greatly decreases, reaching THDU $=5.7 \%$ for $5 \mathrm{kHz}$ carrier frequency at $50 \mathrm{~Hz}$ for the inverter output voltage. In this case we observed an increase in the deforming regime at different frequencies (THDU $=23.4 \%$ for $45 \mathrm{~Hz}$ and THDU $=14 \%$ for $55 \mathrm{~Hz}$ ). 


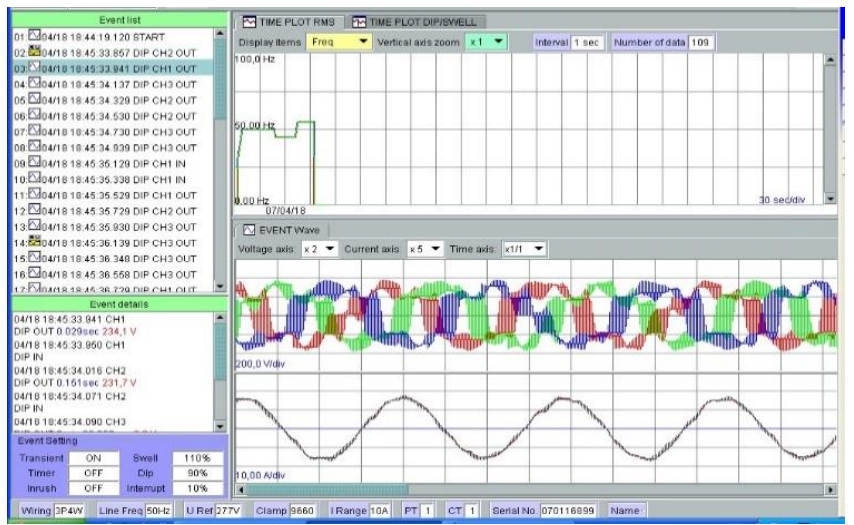

Figure 6. Variation of the frequency and variation of the voltage and electric current curves

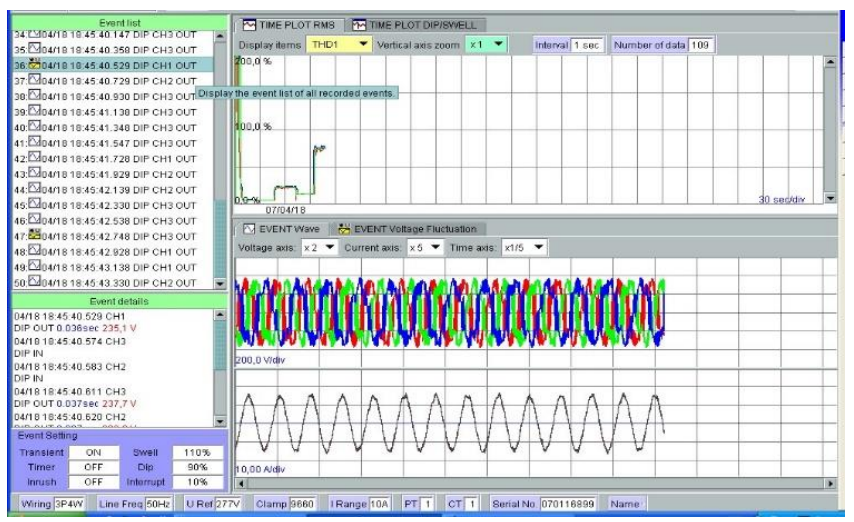

Figure 7. Variation of the total harmonic distortion THDU during the experiment and the variation curves of voltage and electric current

(a)

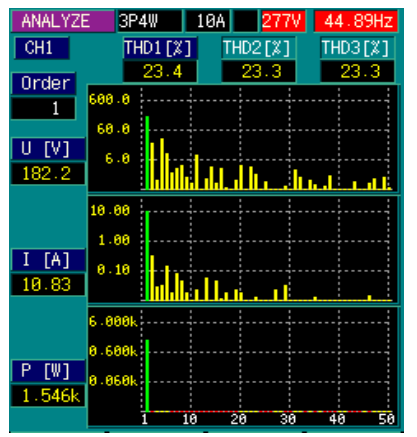

(b)

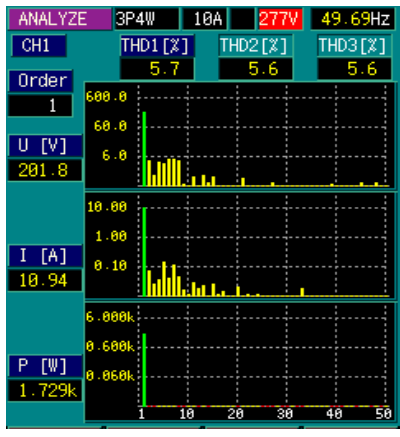

(c)

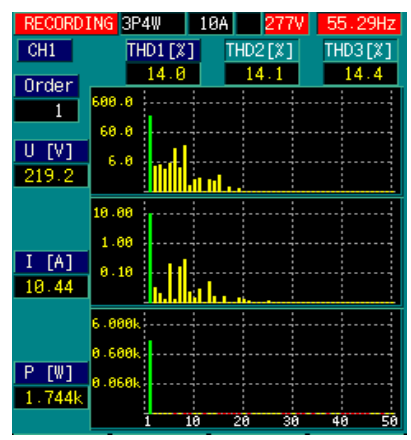

Figure 8. Spectral composition of the inverter output electrical quantities under PWM control, with the carrier frequency $5 \mathrm{kHz}$ : (a) for frequency $45 \mathrm{~Hz}$; (b) for frequency $50 \mathrm{~Hz}$; (c) for frequency $55 \mathrm{~Hz}$

\section{Electricity quality measurements on a modernized production line}

To confirm the experimental results obtained in the laboratory, we performed measurements to study the deforming regime and electricity quality systems introduced by existing shareholders on a production line at a lignite open pit. Measurements were performed with Hioki 3197 apparatus for analyzing the quality of electrical power connected to the transformer station which supplies the technological line equipment. The current and voltage probes were installed in measuring cells at the output of the $2 \times 4$ MVA transformation station.

The carrier machines operating in a continuous mode are driven by asynchronous machines with rated voltages of $6 \mathrm{kV}$ and $400 \mathrm{~V}$. Distribution of ST $20 / 6 \mathrm{kV}$ to electrically operated equipment is made by cable lines with lengths between 350 and $5700 \mathrm{~m}$.

The module of the measuring device connection is given in Figure 9.

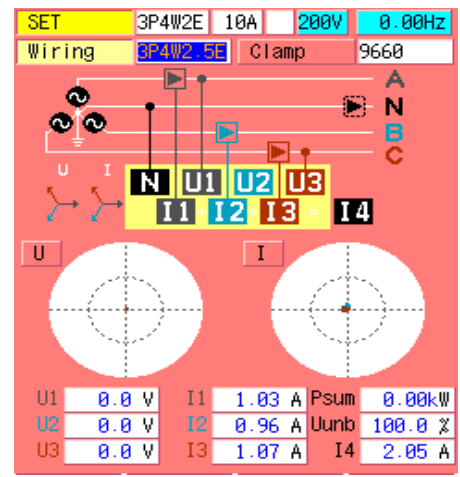

Figure 9. The main window for the mode choice of connection

\subsection{Measurements performed on the excavator}

The measurements were made on the excavator ERc 1400-30/7 with the loader bucket volume 14001 , maximum cutting height $30 \mathrm{~m}$ and the maximum depth of cut $7 \mathrm{~m}$ below the ground level. This excavator has rated voltage $6 \mathrm{kV}$, rotor nominal power $500 \mathrm{~kW}$, installed power $2540 \mathrm{~kW}$ and current $130 \mathrm{~A}$. The bucket wheel drive uses asynchronous motor with a wound rotor (power $500 \mathrm{~kW}$, rated voltage $6000 \mathrm{~V}$, and rotation speed $104.7 \mathrm{rad} / \mathrm{s}$ ).

The motors for actuating rotor arm are pivotally DC squirrel-cage type with output power $2 \times 37 \mathrm{~kW}$, supply voltage $220 \mathrm{~V}$, the speed of rotation between $10 \pi$ and $50 \pi \mathrm{rad} / \mathrm{s}$ and CSF of $P=90 / 132 \mathrm{~kW} / \mathrm{kVA}$.

Further we discuss the results of measurements taken from the power quality analyzer and processed with a personal computer. The measurements were performed in different operating modes of the line that feeds excavator regimens given proper functioning of the excavator, including idle modes.

The measurement results are shown in Figures 10-12, namely the variation of the voltage and the electric current modes (actual and maximum values for a single phase), the values of active and reactive power, the variation of power factor and the variation of distortion factor.

From the analysis of graphs in Figures 10-12 it can be concluded that there is no strong interference with the variation of voltage and the electric current, even the variation of power factor being within normal limits. 


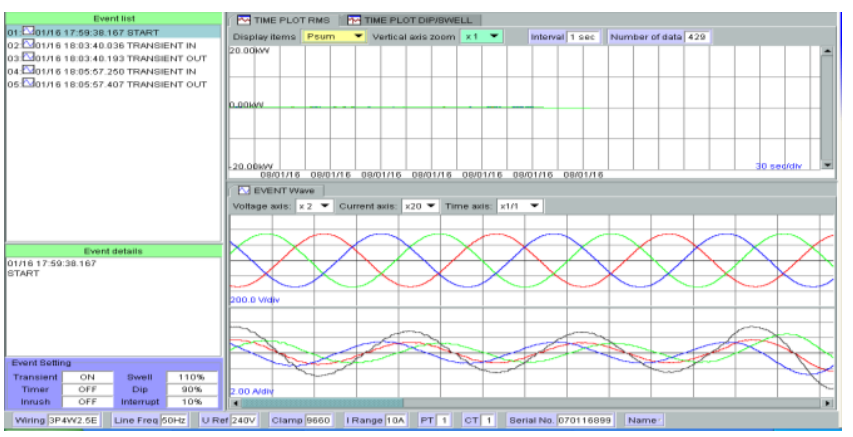

Figure 10. Active power variation and the time variation of voltages and electric currents

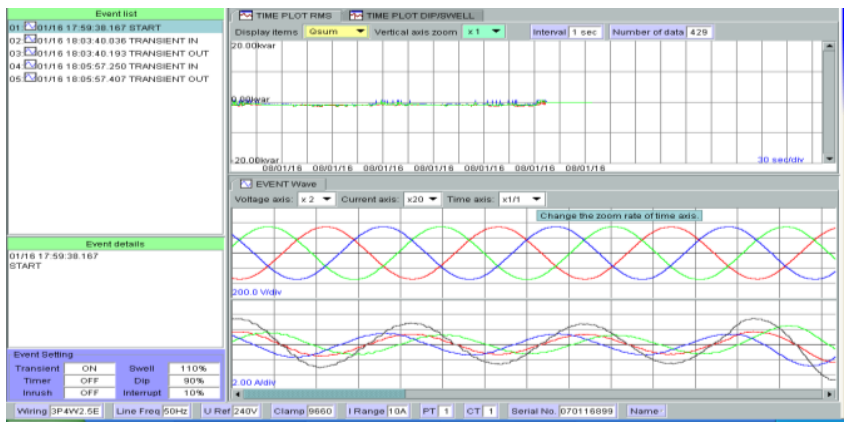

Figure 11. Reactive power variation and the time variation of voltages and electric currents

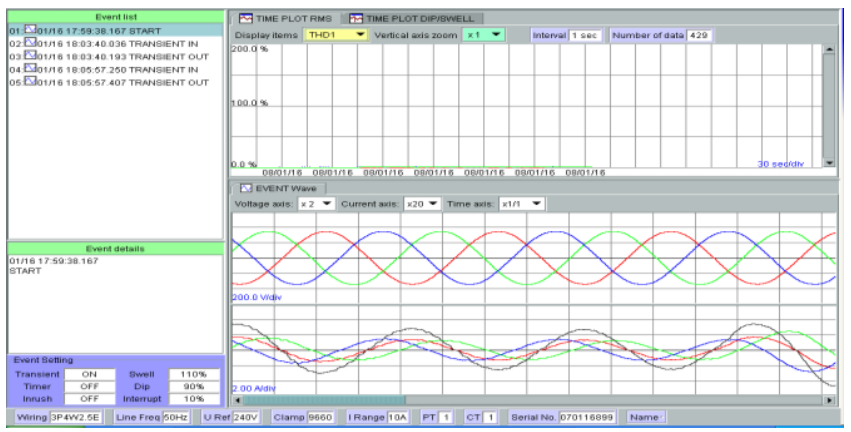

Figure 12. Distortion factor variation and the time variation of voltages and electric currents

As regards the distortion factor, it is reduced. To get some clearer conclusions, we performed measurements shown in Figure 13 which present the data on the measured harmonic values and the time variation of electric current and voltage at different time points. Figure 13 presents the variation of current and voltage curves, the harmonics spectrum of voltage and current as well as certain parameters which are characteristic of voltage, current and power (the effective voltage, the peak voltage, the distortion factor THD in percent, the effective electrical currents, the peak currents, the power factor, the active power values - reactive and apparent).

\subsection{Measurements performed on the excavator conveyor belts}

Below we discuss the results of measurements for the supply line of the T-500, T-501 and MAN-1 conveyor belts electrical drives. The measurements were performed in different operating regimes of the drives on this supply line.

Each belt conveyor is equipped with $6 \mathrm{kV} / 630 \mathrm{~kW}$ drive motors, three-phase motors with wound rotor, starting accomplished by the static converter rotor CSR, type $630 \mathrm{P}$. (a)

(b)
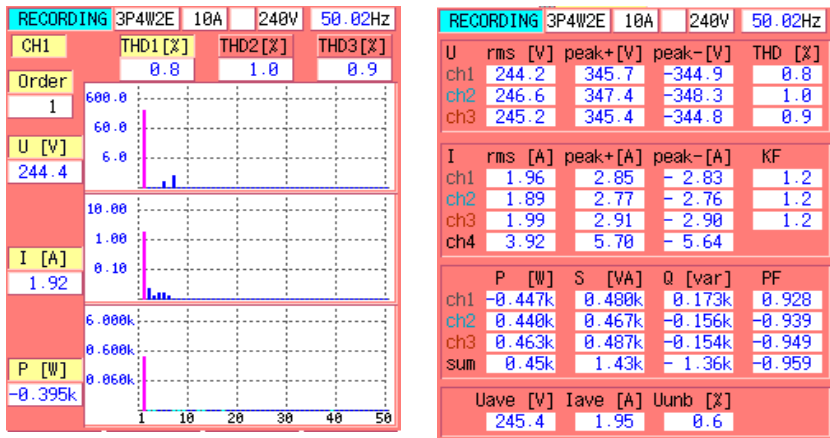

(c)

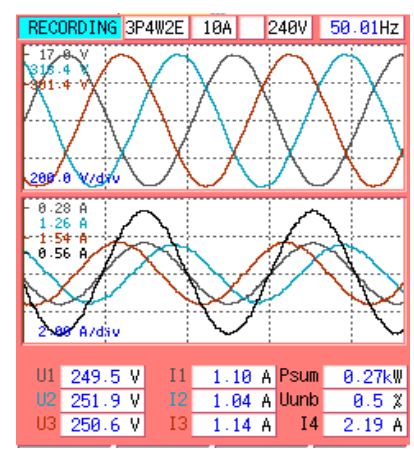

Figure 13. The harmonics spectrum, the effective values, the voltage and the current curves: (a) the harmonics spectrum; (b) the effective values; (c) the voltage and the current curves

The measurement results show mode variation of the voltages and electric currents (actual and maximum values for single phase), the values of active and reactive power, the power factor variation and the variation of the distortion (Figs. 14-16).

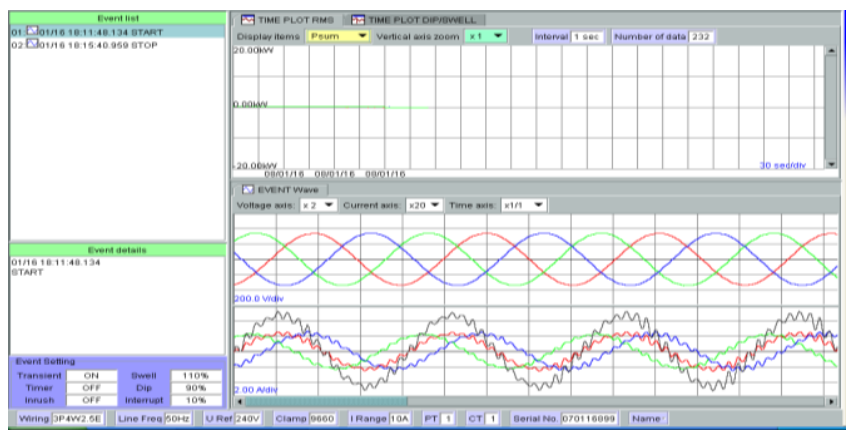

Figure 14. Active power variation and the time variation of voltages and electric currents

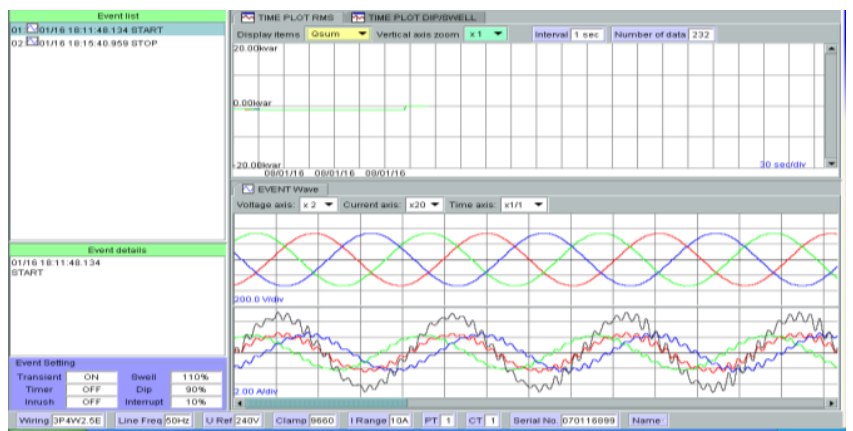

Figure 15. Reactive power variation and the time variation of voltages and electric currents 


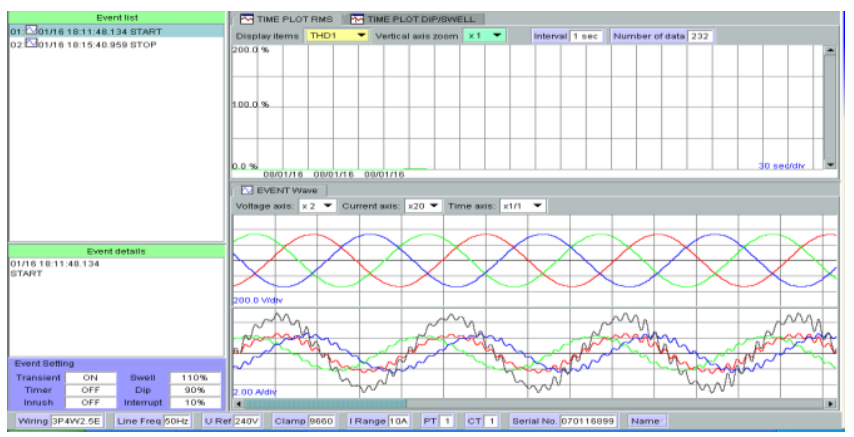

Figure 16. Distortion factor variation and the time variation of voltages and electric currents

From the analysis of graphs in Figures 14-16 it can be concluded that there is no strong interference with the variation of voltage and the electric current.

The power factor variation is insignificant, it is below 0.5 and even lower at higher loads, which may be due to the improper loading of the machines. As regards the distortion factor, it is reduced.

For confirming the obtained results shown in Figure 17, the harmonics amplitudes of electric current and voltage, as well as the indicators of the deforming regime characteristics were calculated. The above measurements were made in idle and load operating regimes of the T-500, T-501 conveyor belts of the E-05 excavator. (a)

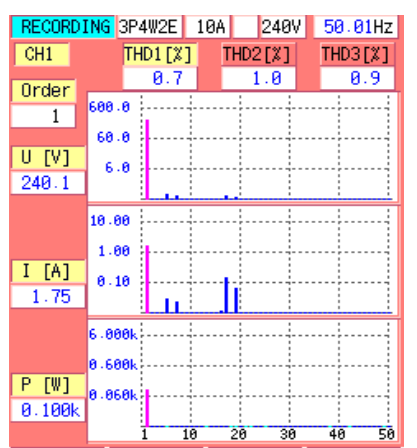

(b)

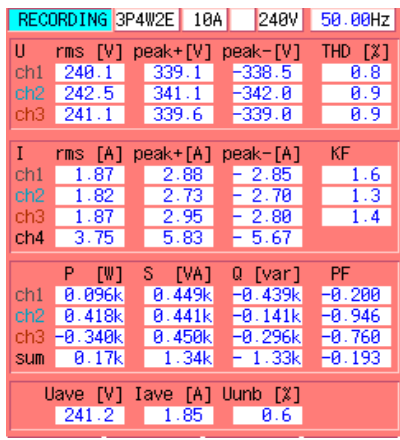

Figure 17. The harmonics spectrum of the voltages and the current at load operation (a); the effective values recorded at load operation (b)

\section{Conclusions}

From the measurement data obtained in the laboratory experimental study it was evident that at the inverter output, the deforming regime is stronger for the voltage than for the electric current. This occurs due to the specific mode of the voltage curves formation at the inverter output, with PWM control.

The laboratory measurement results were substantiated by the measurements made in the analyzed lignite open pits. It allowed to conclude that on a modernized production line equipped with rectifiers with width modulation, the harmonic regime is significantly reduced in comparison with technological lines which are not modernized and still use semicontrolled rectifiers, thus introducing a fairly pronounced harmonic regime.

From the measurement analysis it was inferred that in the case of modernized production lines there is no strong interference with the voltage and current variation, but it was found that the power factor variation is inadequate, being 0.5 and even lower at higher load values, which may be due to the longer electric lines or the impact of other users.

\section{Acknowledgements}

The authors state that this research received no specific grant from any funding agency in the public, commercial, or not-for-profit sectors.

\section{References}

[1] Buta, A., Milea, L., \& Pana, A. (2001). Calitatea energiei. Bucharest, Romania: AGIR Publishing House.

[2] Handra, A.D., \& Popescu, F.G. (2011). Creşterea eficienţei energetice $\hat{\imath}$ mineritul de suprafaţă. Bucharest, Romania: Universitas Publishing House.

[3] Marcu, M.D., \& Borca, D. (1999). Convertoare statice în acţionări electrice. Bucharest, Romania: Topoexim Publishing House.

[4] Pasculescu, D., Pana, L., Pasculescu, V.M., \& Deliu, F. (2019). Economic criteria for optimizing the number and load factor of mining transformers. Mining of Mineral Deposits, 13(2), 1-16. https://doi.org/10.33271/mining13.02.001

[5] Stroescu, A., \& Paun, M. (2004). Instalaţii electrice ale exploatărilor miniere de suprafaţă. Bucharest, Romania: Script Publishing House.

[6] Felea, I., \& Dale, E. (1999). Efectele energetice ale funcţionării motorului asincron în regim deformant şi nesimetric. Revista Energetica, (11).

[7] Radu, S.M., Rosianu, C., \& Stoicoiu, I. (2010). Upgrading electrical drives control at the bucket wheel excavators. Conference on Environment and Mineral Processing, (3), 97-100.

[8] Popescu, F.G., Arad, S., Marcu, M., \& Pana, L. (2013). Reducing energy consumption by modernizing drives of high capacity equipment used to extract lignite. International Multidisciplinary Scientific GeoConference-SGEM, Energy and Clean Technologies, 183-190. https://doi.org/10.5593/SGEM2013/BD4/S17.024

[9] Dumitrescu, I., Cozma, B.Z., \& Urdea, G.B. (2017). Modernization of EsRc1400 excavator buckets with the help of CAD/CAE software. International Multidisciplinary Scientific GeoConference-SGEM, Exploration and Mining, 17(13), 555-561. https://doi.org/10.5593/SGEM2017/13/S03.071

[10] Popescu, F.D., Radu, S.M, Kotwica, K., Andras, A., \& Kertesz (Brinas), I. (2019). Simulation of the time response of the ERc 1400-30/7 bucket wheel excavator's boom during the excavation process. Sustainability, 11(16), 4357. https://doi.org/10.3390/su11164357

[11] Beshta, O.S. (2012). Electric drives adjustment for improvement of energy efficiency of technological processes. Naukovyi Visnyk Natsionalnoho Hirnychoho Universytetu, (4), 98-107.

[12] Taran, I., \& Klymenko, I. (2018). Analysis of hydrostatic mechanical transmission efficiency in the process of wheeled vehicle braking. Transport Problems, 12(SE), 45-56. https://doi.org/10.20858/tp.2017.12.se.4

[13] Popescu, F.D., Radu, S.M, Andras, A., \& Kertesz (Brinas), I. (2019). A grafo-numeric method of determination of the operation power of the rotor of EsRc-1400 bucket wheel excavator using computer simulation in SolidWorks. MATEC Web of Conferences, (290), 04007. https://doi.org/10.1051/matecconf/201929004007

[14] Dryzhenko, A., Moldabayev, S., Shustov, A., Adamchuk, A., \& Sarybayev, N. (2017). Open pit mining technology of steeply dipping mineral occurences by steeply inclined sublayers. International Multidisciplinary Scientific GeoConference Surveying Geology and Mining Ecology Management, 17(13), 599-606. https://doi.org/10.5593/sgem2017/13/s03.076

\section{Аналіз гармонік струму і напруги, викликаних системами приводу багатоковшового екскаватора}

\section{Ф.Г. Попеску, Д. Паскулеску, М.Д. Марку, В.М. Паскулеску}

Мета. Дослідження та аналіз гармоніки струму й напруги, що з'являються в мережі змінного струму, а також деформуючого режиму, заданого системами приводу багатоковшового екскаватора на технологічній лінії кар'єра. 
Методика. Виконано лабораторні вимірювання для дослідження змінного деформуючого режиму, створюваного приводними системами зі статичним перетворювачем частоти - асинхронним двигуном. Виміри проводилися на лабораторному стенді 3 наступним обладнанням: асинхронний двигун $\left(P_{n}=3\right.$ кВт), непрямий статичний перетворювач частоти VARISPEED F7, генератор постійного струму, що працює як тормоз навантаження на приводний двигун, обладнання для аналізу якості енергії. Вимірювання проводились при запуску, зміні частоти та при різних значеннях напруги й навантаження, включаючи роботу без навантаження.

Результати. Встановлено, що на виході інвертора деформуючий режим сильніше в разі напруги, ніж в разі електричного струму, що відбувається внаслідок особливого режиму формування кривих напруги на виході інвертора. Визначено, що на модернізованій виробничої лінії, що складається $з$ оснащених випрямлячами 3 широтною модуляцією, спостерігалося, що гармонійний режим значно знижений у порівнянні з технологічними лініями, що не модернізуються і які використовують напівкеровані випрямлячі, тим самим, що вводять у режим гармоніки досить яскраво виражений гармонійний режим. Виявлено, що в разі модернізованих виробничих ліній немає суттєвих перешкод у зміні напруги й струму, але виявлено, що зміна коефіцієнта потужності $€$ неадекватною, становить 0.5 і менше при більш високих значеннях навантаження, що пов'язано з більш довгими електричними лініями або впливом інших користувачів.

Наукова новизна. Розроблено принципово новий підхід до експериментальних вимірів якості електроенергії та аналізу деформуючого режиму, викликаного системами електроприводу.

Практична значимість. Отримані результати дозволяють модернізувати якість системи електропостачання та підвищити якість електроенергії для виїмкової техніки при відкритій розробці родовищ.

Ключові слова: багатоковшовий екскаватор, деформуючий режим, системи приводу, електричний струм, лігнітовий кар'єр, вимірювання, якість, напруга

\section{Анализ гармоник тока и напряжения, вызванных системами привода многоковшового экскаватора}

\section{Ф.Г. Попеску, Д. Паскулеску, М.Д. Марку, В.М. Паскулеску}

Цель. Исследование и анализ гармоники тока и напряжения, появляющихся в сети переменного тока, а также деформирующего режима, заданного системами привода многоковшового экскаватора на технологической линии карьера.

Методика. Выполнены лабораторные измерения для исследования искажающего деформирующего режима, создаваемого приводными системами со статическим преобразователем частоты - асинхронным двигателем. Измерения проводились на лабораторном стенде со следующим оборудованием: асинхронный двигатель $\left(P_{n}=3\right.$ кВт), непрямой статический преобразователь частоты VARISPEED F7, генератор постоянного тока, работающий как тормоз нагрузки на приводной двигатель, оборудование для анализа качества энергии. Измерения проводились при запуске, изменении частоты и при различных значениях напряжения и нагрузки, включая работу без нагрузки.

Результаты. Установлено, что на выходе инвертора деформирующий режим сильнее в случае напряжения, чем в случае электрического тока, что происходит вследствие особого режима формирования кривых напряжения на выходе инвертора. Определено, что на модернизированной производственной линии, состоящей из оснащенных выпрямителей с широтной модуляцией, наблюдалось, что гармонический режим значительно снижен по сравнению с технологическими линиями, которые не модернизируются и которые используют полууправляемые выпрямители, тем самым вводящие в режим гармоники достаточно ярко выраженный гармонический режим. Выявлено, что в случае модернизированных производственных линий нет сильных помех в изменении напряжения и тока, но обнаружено, что изменение коэффициента мощности неадекватно, составляет 0.5 и менее при более высоких значениях нагрузки, что связано с более длинными электрическими линиями или влиянием других пользователей.

Научная новизна. Разработан принципиально новый подход к экспериментальным измерениям качества электроэнергии и анализа деформирующего режима, вызванного системами электропривода.

Практическая значимость. Полученные результаты позволяют модернизировать системы электроснабжения и повысить качество электроэнергии для выемочной техники при открытой разработке месторождений.

Ключевые слова: многоковшовый экскаватор, деформирующий режим, системы привода, электрический ток, лигнитовый карьер, измерения, качество, напряжение

\section{Article info}

Received: 5 May 2020

Accepted: 2 November 202020

Available online: 7 December 2020 